\title{
Frequency of Maxillofacial Injuries and Accompanying Types of Maxillofacial Fractures
}

\author{
Sedat Altay ${ }^{1}$ (D) , Umut Payza ${ }^{2}$ (iD , Nezahat Erdoğan ${ }^{1}$ (iD , Muhsin Engin Uluç ${ }^{1}$ (iD
}

${ }^{1}$ Izmir Katip Celebi University Ataturk Research and Training Hospital, Department of Radiology, İzmir, Turkey

${ }^{2}$ Izmir Katip Celebi University, Ataturk Training and Teaching Hospital, Emergency Department, İzmir, Turkey

Sedat ALTAY

Umut PAYZA

Nezahat ERDOĞAN

Muhsin Engin ULUÇ

Correspondence: Sedat Altay Izmir Katip Celebi University Ataturk Research and Training Hospital, Department of Radiology, Izmir, Turkey

Phone: +905332435440

E-mail: sedataltay@yahoo.com

$\begin{array}{ll}\text { Received } & : 15 \text { March } 2021 \\ \text { Accepted } & : 15 \text { August } 2021\end{array}$

\begin{abstract}
Objective: In this study, it was aimed to examine the characteristics, causes of trauma, and age distribution of maxillofacial fractures in patients admitted to the emergency department as a result of blunt maxillofacial trauma.

Materials and Methods: Between 01.01.2015 and 31.12.2019, 1248 patients who were admitted to the emergency department with maxillofacial trauma were evaluated retrospectively. Patients who underwent CT examination and were diagnosed with fracture were included in our study.

Results: The median age of the patients was 32 years, and $71.2 \%$ of them were male. Trauma-related fractures were detected in 239 (19.2\%) of 1248 patients with maxillofacial trauma. The affected group of participants comprised of individuals of younger age and male gender. The main mechanisms of trauma were traffic accidents and falls from height. Orbital fractures were the most common, followed by maxillary bone fractures. Severe maxillofacial fractures were often accompanied by traumatic brain injuries. The mortality rate was low $(0.4 \%)$ in patients with isolated maxillofacial trauma compared to patients with polytrauma (16\%) ( $p=0.001)$. In our study, it has been shown that face AIS (Odds ratio: 2.79 ) and Glasgow coma score (0dds ratio: 0.98 ) can predict mortality in trauma patients with multivariable regression analysis.

Conclusion: As a result of this study, we determined the relationship between variables associated with common traumatic injury in the maxillofacial region. Age, gender, and injury mechanism are of great clinical importance in the identification and prediction of traumatic maxillofacial fractures.
\end{abstract}

Keywords: Traffic Accidents, Maxillofacial Injuries, X-Ray Computed Tomography, Mortality

\section{Üst Çene-Yüz Yaralanmalarının Sıklığı ve Eşlik Eden Üst Çene-Yüz Kıııklarının Türleri \\ ÖZET}

Amaç: Bu çalışmada künt üst çene-yüz (ÜÇ-Y) travma sonucu acil servise başvuran hastalarda ÜÇ-Y kıııkların özellikleri, travma nedenleri ve yaş dağılımının incelenmesi amaçlanmıştır.

Hastalar ve Yöntem: 01.01.2015 - 31.12.2019 tarihleri arasında acil servise ÜÇ-Y travması ile başvuran 1248 hasta geriye dönük olarak değerlendirildi. Çalışmamıza bilgisayarlı tomografi incelemesi yapılan ve kırık tanısı konulan hastalar dahil edildi.

Bulgular: Hastaların ortanca yaşı 32 idi ve \% 71.2'si erkekti. ÜÇ-Y travmalı 1248 hastanın 239' unda (\%19.2) travmaya bağlı kırık tespit edildi. Etkilenen katılımc grubu, daha genç yaştaki ve erkek cinsiyetteki bireylerden oluşmuştur. Travmanın ana mekanizmaları trafik kazaları ve yüksekten düşmelerdi. Göz çukuru kırıkları en yaygın olanıydı ve bunu üst çene kemik kırıkları izledi. Ciddi ÜÇ-Y kırıklara sıkıkla travmatik beyin yaralanmaları eşlik ediyordu. İzole ÜÇ-Y travmalı hastalarda, çoklu travmalı hastalara göre (\% 16) ölüm oranı düşüktü (\% 0.4) $(p=0.001)$. Çalışmamızda çok değişkenli gerileme analizi ile travma hastalarında yüz AIS (Odds oranı: 2.79) ve Glasgow koma skorunun (Odds oranı: 0.98) ölüm oranını öngörebildiği gösterilmiştir.

Sonuç: Bu çalışma sonucunda ÜÇ-Y bölgesinde sık görülen travmatik yaralanma ile ilişkili değişkenler arasındaki ilişkiyi belirledik. Travmatik ÜÇ-YI kıııların tanımlanmasında ve öngörülmesinde yaş, cinsiyet ve yaralanma mekanizması büyük klinik öneme sahiptir.

Anahtar Kelimeler: Trafik Kazaları, Üst Çene Yaralanmaları, Yüz yaralanmaları, X-Ray Bilgisayarlı Tomografi, Ölüm Oranı 
M axillofacial traumas have become an important health problem worldwide with the increase in traffic accidents. Given that the maxillofacial bones are anatomically aligned in a certain balance and their close proximity to the central nervous system, traumatic injuries are of critical importance. (1). Worldwide, the most common cause of maxillofacial fractures (MF) is traffic accidents. MF is seen less frequently due to falls, drowning, sports injuries, and work accidents (2-4). Previous studies in the literature have shown that MF is mostly detected in men and between the ages of 21-30. The male/female ratio has been reported between $2 / 1$ and $11 / 1$ in the literature (2,5-7). MF often leads to facial asymmetry, deformity, loss of chewing and visual function, and the need for long-term treatment in patients.

The most reliable method to determine the presence and extent of MF in patients with maxillofacial trauma is maxillofacial computed tomography (CT) (3). In patients admitted to the emergency room with polytrauma, maxillofacial CT should be the first choice of imaging modality in the presence of suspected maxillofacial injury. This study, it was aimed to determine the frequency and distribution of MF in patients admitted to the emergency department with maxillofacial trauma and who had CT scanning performed.

\section{Material and Method}

\section{Study Design}

In this study, 239 patients who had MF among 1248 patients admitted to the emergency department of our hospital with maxillofacial trauma between 01.01.2015 and 31.12.2019 were included. Maxillofacial CT examinations of the patients were reinterpreted by two radiologists experienced in head and neck radiology.

The patients included in our study were retrospectively evaluated in terms of age, gender, Glasgow Coma Score (GCS) value, face-AIS (Abbreviated Injury Scale), presence of MF, and fracture location. Clinical evaluations were obtained from medical records and consultation data made at the time of initial admission to the emergency department.

\section{Statistical Analysis}

SPSS 24.0 (Statistical Package for Social Sciences version - SPSS Inc. Chicago, Illinois, USA) package program was used for statistical analysis. The difference between categorical variables was evaluated with the chi-square test. Multivariate regression analysis was used to evaluate the relationship between variables and mortality in patients with polytrauma, and the Odds ratio was calculated with a $95 \%$ confidence interval $(\mathrm{Cl})$ for the values. A p-value of $<0.05$ was considered significant.

\section{Results}

The mean age of the patients included in the study was $32 \pm 12.9$ years and $71.2 \%$ of the patients were male. The mechanism of maxillofacial trauma was due to traffic accidents in $49 \%$ of the patients, falling from a height of $27 \%$, and other causes in $24 \%$. The demographic data of the patients are presented in table 1.

Table 1. Demographic data of the patients, gender, cause of trauma, and deaths due to trauma are observed in the table

\begin{tabular}{|l|l|c|c|}
\hline \multicolumn{2}{|c|}{} & $\begin{array}{c}\text { Maxillofacial } \\
\text { fracture } \\
\text { patients } \\
\text { diagnosed }\end{array}$ & $\begin{array}{c}\text { The rate in } \\
\text { percentage } \\
(\%)\end{array}$ \\
\hline Age & $32 \pm 12.9$ & - \\
\hline \multirow{2}{*}{ Gender } & Woman & 69 & 28,8 \\
\cline { 2 - 4 } & Male & 170 & 71,2 \\
\hline \multirow{3}{*}{$\begin{array}{l}\text { Reason for } \\
\text { temper }\end{array}$} & Traffic accident & 117 & 49 \\
\cline { 2 - 4 } & Falling from high & 64 & 27 \\
\cline { 2 - 4 } & $\begin{array}{l}\text { Other causes of } \\
\text { trauma }\end{array}$ & 58 & 24 \\
\hline Death & \multicolumn{2}{|c}{7,2} \\
\hline
\end{tabular}

The distribution and location of MFs following maxillofacial trauma are summarized in table 2 . In polytraumatic patients, $42 \%$ of MF patients with associated trauma had skull base fractures, $54 \%$ traumatic brain injury (TBI), 29 $\%$ thorax injury, $19 \%$ traumatic injury to the abdomen, and $52 \%$ long bone fractures. The face-AIS score corresponded to grade II in $61 \%$ of the patients, grade I in $37 \%$, and grade III in the remaining $2 \%$. The mean GCS value of the patients at the time of admission to the emergency department was found to be $11.3 \pm 2.4$. The mortality rate due to trauma in the emergency service of patients diagnosed with MF was $7.2 \%$.

The most common cause of trauma in patients diagnosed with MF was found to be a traffic accident, with statistical significance compared to the other groups. $(p<0.001)$. Young age $(<35)$ and male gender were predominant in this patient group $(p<0.001)$. Multivariable regression analysis shows that face-AIS (Odds ratio: 1.35 (95\% Cl: 1.120--1.561)) and GCS (Odds ratio: 2.79 (95\% Cl: 2.645-2.983)) reliably predict mortality in patients diagnosed with MF. 
Table 2. Distribution and location of Maxillofacial fractures monitored as a result of maxillofacial trauma, Face-AIS score, accompanying injury in polytrauma are shown in the table.

\begin{tabular}{|c|c|c|c|}
\hline & & $\begin{array}{l}\text { Patients diagnosed with a } \\
\text { maxillofacial fracture }\end{array}$ & $\begin{array}{l}\text { The rate in percentage } \\
(\%)\end{array}$ \\
\hline \multicolumn{2}{|c|}{ Glasgow coma scale (when entering the emergency room) } & $11.3 \pm 2.4$ & - \\
\hline \multirow{3}{*}{ Face- AIS score } & I. degree & 88 & 37 \\
\hline & II. degree & 146 & 61 \\
\hline & III. degree & 5 & $2 n d$ \\
\hline \multirow{5}{*}{$\begin{array}{l}\text { Accompanying injury in } \\
\text { polytrauma }\end{array}$} & Skull base fractures & one hundred & 42 \\
\hline & Traumatic brain injury & 129 & 54 \\
\hline & Rib cage injury & 69 & 29 \\
\hline & Abdominal injury & 45 & 19 \\
\hline & Long bone fractures & 124 & 52 \\
\hline \multirow{7}{*}{ Maxillofacial fracture } & Orbital fractures - blow out & 127 & 53 \\
\hline & Orbital fractures - linear, non-displaced & 138 & 58 \\
\hline & Maxilla & 114 & 48 \\
\hline & Mandible & 83 & 35 \\
\hline & Nasal bone & 92 & 38 \\
\hline & Zygomatic arch & 68 & 28 \\
\hline & Ethmoid bone & 76 & 32 \\
\hline
\end{tabular}

\section{Discussion}

Traffic accidents cause an average of more than 1.2 million deaths and 20-50 million people to be injured or disabled annually worldwide, and it is an important public health problem in our country as well as all over the world (8). In the global situation report published by the World Health Organization in 2015, it was reported that deaths from traffic accidents occur most commonly among the 15-29 age group. (8). Maxillofacial trauma most frequently develops due to traffic accidents (2). In our study, 239 patients with MF among 1248 patients who were admitted to the emergency department due to maxillofacial trauma were evaluated retrospectively. In our patient group, the most common cause of trauma was found to be a traffic accident (49\%). As seen in the literature, the male gender (71.2\%) and the young age group were predominantly affected, and orbital fractures (Fig. 1) (53\% and 58\%) were the most common, followed by maxillary fractures (Fig. $1,2)(48 \%)$. In accordance with the literature, MF was most often accompanied by traumatic brain injury (54\%) and long bone fractures $(52 \%)$ in our study.
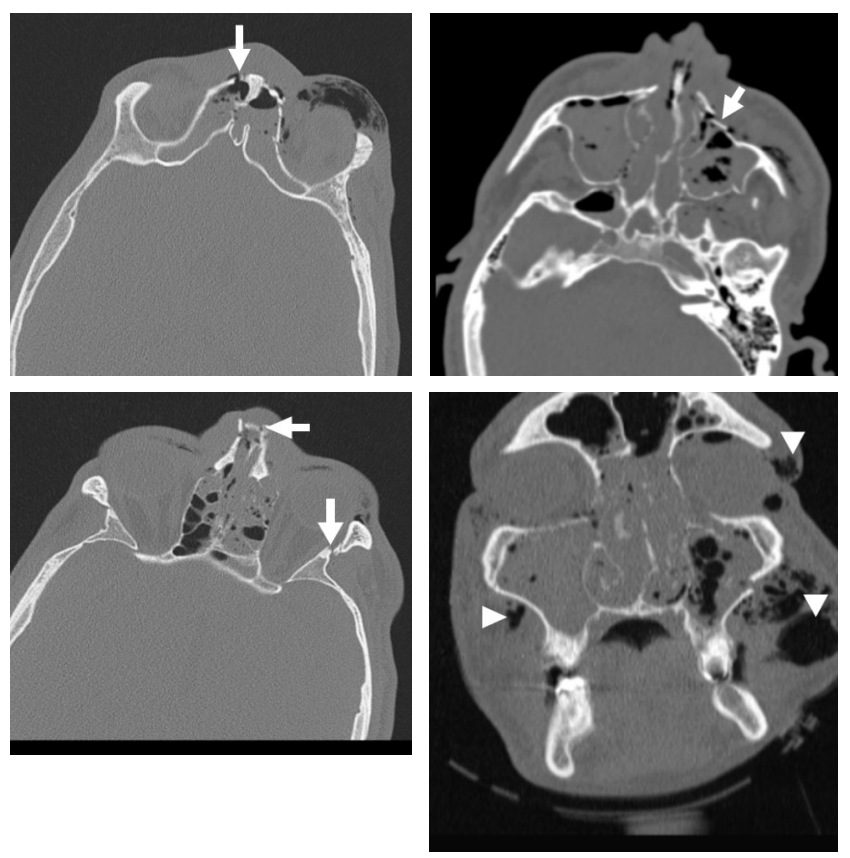

Figure 1. In a 45-year-old male patient fractures (arrows) in the maxillary bone, the ethmoid bone, nasal septum and frontal bone in the axial $(a, b, c)$ and coronal $(d)$ sections of unenhanced maxillofacial CT performed under emergency conditions following traffic accident. Significant air was observed under the skin secondary to trauma(arrowheads). 

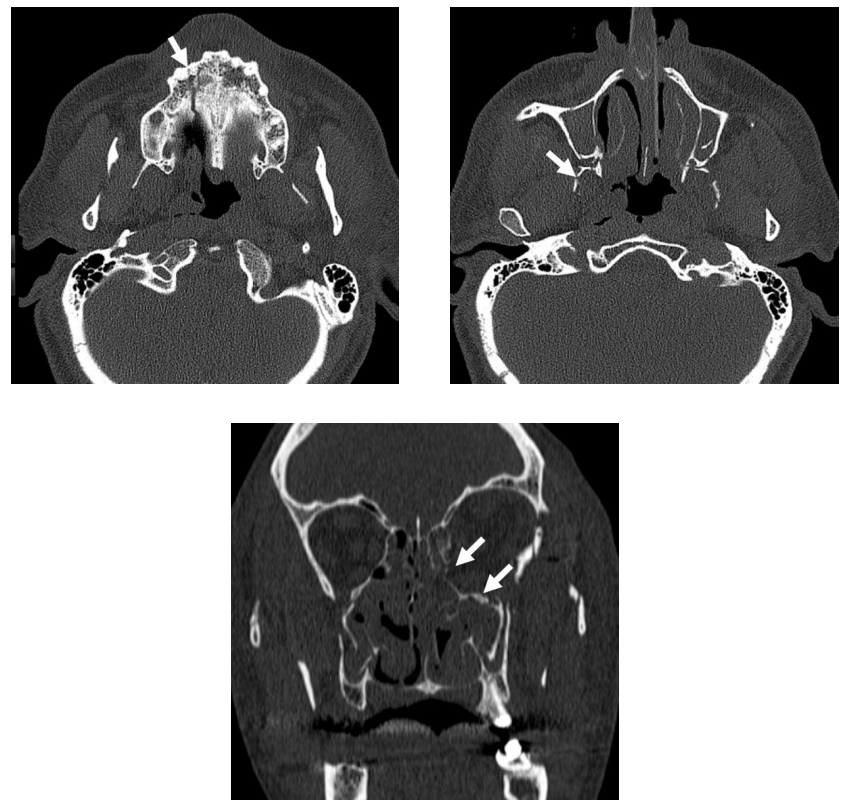

Figure 2. In a 50-year-old male patient, fractures in the anterior, lateral, and base of the right maxillary bone (a), pterygoid bones, and the base of the right maxillary bone in the axial $(a, b)$ and coronal (c) unenhanced maxillofacial CT scans(arrows).

Similar to our study, $62-79.2 \%$ of the affected patients were male in previous studies evaluating the results from emergency room admissions and traffic accidents (9.10). In studies that included patients diagnosed with MF from those admitted to the emergency department due to traffic accidents and maxillofacial trauma, similar to our study, facial bone fractures were most commonly found in a group of patients aged 21-30 years $(1,2)$. In the literature on patients diagnosed with MF, mandible fractures were reported to be most common in some studies (Fig. 3) (2, 11), while in other groups of studies, similar to our study, zygomatic bone (Fig. 4), frontal and orbital fractures were most frequently seen. $(12,13)$. MF was most commonly accompanied by traumatic brain injury in the literature in parallel with our study. Al- Hassani et al. (14) have found TBI in $8 \%$ of patients presenting with maxillofacial trauma and reported as poor prognosis criterion. In our study, the rate of TBI detection in patients presenting with maxillofacial trauma at $10.3 \%$ is consistent with the literature.

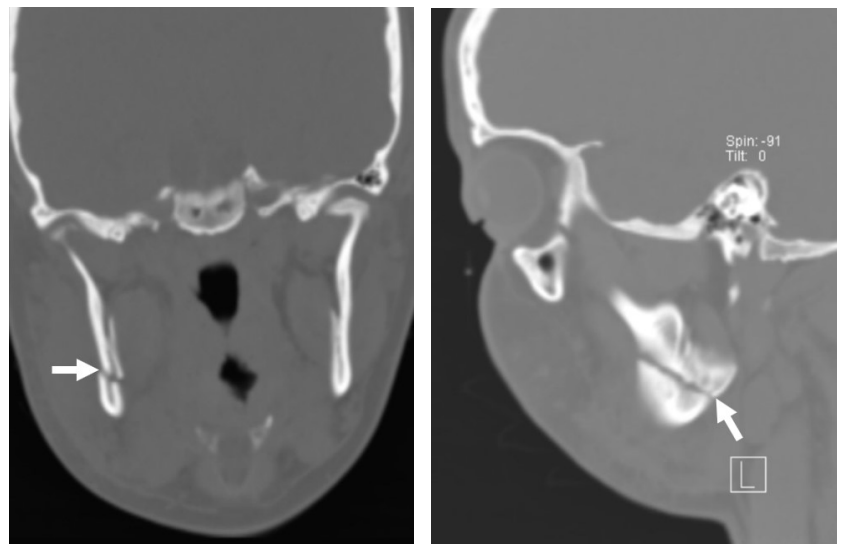

Figure 3. In a 25-year-old male patient, angulus fracture in the right mandible due to fall in a 25 -year-old male patient in the coronal (a) and sagittal (b) unenhanced CT images (arrows).
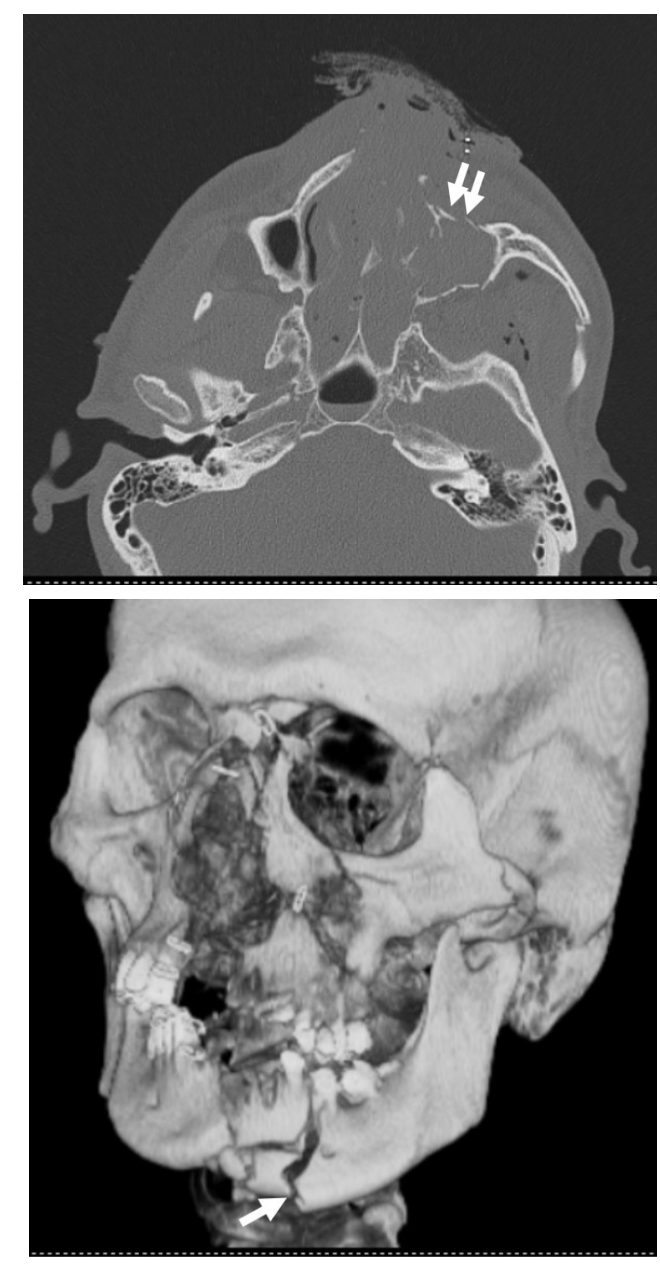

Figure 4. A 32-year-old male patient showed multiple maxillofacial smash-style fractures in axial CT (a) and volume rendering reformat (b) images after an in-vehicle traffic accident. 
Püsküllüoğlu et al. (15) have reported a GCS value of 14-15 in patients who presented with a traffic accident. Mirzai et al. (16) have found that the GCS value of $75.1 \%$ of patients with multiple traumas affecting at least one organ system after a traffic accident was between 14-15. Al-Hassani et al. (14) found the mean GCS value of patients with maxillofacial trauma to be 11.6, which is very close to our study. In the same study, face-AIS score distribution was reported similarly to our study (i.e. grade I: $33 \%$; grade II: $65.7 \%$; grade III: $1.3 \%$ ) (14). Similarly, in this study, the face-AIS score and GCS value have been reported as important factors in predicting mortality in patients with maxillofacial trauma presenting to the emergency service (14).

Our study has some limitations. Due to the retrospective nature of our study, it was difficult to access the clinical data of the patients. Motion artifacts observed during CT scan in some of the patients with maxillofacial trauma caused difficulties in identifying the location of the fractures. Since our hospital is a tertiary health center, the high number of patients with polytrauma referred from surrounding hospitals has also led to a high frequency of MF among patients with polytrauma, which may have caused bias.

\section{Conclusion}

In conclusion, maxillofacial trauma is a clinically common type of trauma that causes moderate to severe injury. The most common fracture types are blow-out type orbital fractures, linear nondisplaced orbital floor fractures, and maxilla fractures. The presence of MF in polytrauma patients with maxillofacial trauma should be investigated with maxillofacial CT examination. In this patient group, face-AIS and on-admission GCS are reliable biomarkers to predict mortality.

\section{Conflict of Interest}

The authors have not declared any conflicts of interest.

\section{Financial Support}

The authors have not declared any financial support.

\section{References}

1. Schaftenaar E, Bastiaens GJH, Simon ENM, Merkx MAW. Presentation and management of maxillofacial trauma in Dar Es Salaam, Tanzania. East Afr Med J. 2009;86(6):254-8.

2. Farias IPSE, Bernardino ÍM, Nóbrega LMD, Grempel RG, D'Avila S. Maxillofacial trauma, etıology and profile of patıents: an exploratory study. Acta Ortop Bras. 2017 Nov-Dec;25(6):258-261.

3. Alves LS, Aragão I, Sousa MJ, Gomes E. Pattern of maxillofacial fractures in severe multiple trauma patients: a 7-year prospective study. Braz Dent J. 2014 Nov-Dec;25(6):561-4.
4. Torgersen S, Tornes K. Maxillofacial fractures in a Norwegian district. Int J Oral Maxillofac Surg. 1992;21(6):335-8.

5. Gassner R, Tuli T, Hächl O, Rudisch A, Ulmer H. Cranio-maxillo- facial trauma: a 10 year review of 9543 cases with 21067 injuries. J CranioMaxillofacial Surg. 2003;31(1):51-61.

6. Al Ahmed HE, Jaber MA, Abu Fanas $\mathrm{SH}$, Karas $\mathrm{M}$. The pattern of maxillofacial fractures in Sharjah, United Arab Emirates: A review of 230 cases. Oral Surg Oral Med Oral Pathol Oral Radiol Endodontol. 2004;98(2):166-70.

7. Almasri M. Severity and causality of maxillofacial trauma in the Southern region of Saudi Arabia. Saudi Dent J. 2013;25(3):107-10.

8. World Health Organization. Global status report on road safety 2015. http://www.who.int/violence_injury_prevention/ro ad_safety_ status/2015/en/ 16.06.2016

9. Sözüer EM, Yıldııım C, Şenol V, Naçar M, Günay O. Trafik kazalarında risk faktörleri. Ulus Travma Acil Cerrahi Derg 2000; 6: 237- 40.

10. Yousefzadeh-Chabok S, Ranjbar-Taklimie F, Malekpouri R, Razzaghi A. A time series model for assessing the trend and forecasting the road traffic accident mortality. Arch Trauma Res 2016; 5: e36570.

11. Park K-P, Lim S-U, Kim J-H, Chun W-B, Shin D-W, et al. Fracture patterns in the maxillofacial region: a four-year retrospective study. J Korean Assoc Oral Maxillofac Surg. 2015;41(6):306.

12. Alves LS, Aragão I, Sousa MJC, Gomes E. Pattern of maxillofacial fractures in severe multiple trauma patients: a 7-year prospective study. Braz Dent J. 2014;25(6):1-4.

13. Scheyerer MJ, Döring R, Fuchs N, Metzler $P$, Sprengel $K$, et al Maxillofacial injuries in severely injured patients. J Trauma Manag Outcomes. 2015;9:4.

14. Al-Hassani A, Ahmad K, El-Menyar A, Abutaka A, Mekkodathil A, Peralta R, Al Khalil M, Al-Thani H. Prevalence and patterns of maxillofacial trauma: a retrospective descriptive study. Eur J Trauma Emerg Surg. 2019 Jun 21.

15. Püsküllüoğlu $S$, Acikalin $A Y$, Mehmet $A Y$, Kozaci $N$, Akkan $A V$, et al. Analysis of adult trauma patients admitted to emergency department. Cukurova Medical Journal 2015; 40: 569-79.

16. Mirzai H, Yağlı N, Tekin İ. Celal Bayar Üniversitesi Tıp Fakültesi acil birimine başvuran kafa travmalı olguların epidemiyolojik ve klinik özellikleri. Ulus Travma Acil Cerrahi Derg 2005; 11: 146-52. 